REVIEW

\title{
Cytokines in the seronegative spondyloarthropathies and their modification by TNF blockade: a brief report and literature review
}

\author{
C Keller, A Webb, J Davis
}

Ann Rheum Dis 2003;62:1128-1132. doi: 10.1136/ard.2003.011023

Rheumatoid arthritis (RA) is a disease well characterised by proinflammatory cytokine secretion (particularly tumour necrosis factor, interferon gamma, interleukin (IL) 1, and IL6). Less has been reported about the cytokine profiling in the spondyloarthropathies (SpA). Several trials suggest that, similar to RA, proinflammatory cytokines are globally expressed in the SpA. However, other studies report a down regulation of these cytokines in the $\mathrm{SpA}$, with a relative anti-inflammatory polarisation (featuring increases in IL4, IL5, and IL10). This review summarises current published reports and the variation in cytokine data in the SpA. Additionally, results of cytokine profiles in patients with ankylosing spondylitis before and after treatment with etanercept are reported.

See end of article for authors' affiliations

Correspondence to: Assistant Professor J C Davis, University of California San Francisco, 533 Parnassus Avenue, Box 0633, Room U383 San Francisco, CA 94143, USA; jdavis@medicine. ucsf.edu

Accepted 30 July 2003
$\mathrm{T}$ he seronegative spondyloarthropathies $(\mathrm{SpA})$ are a group of disorders characterised by tissue inflammation, constitutional symptoms, and joint destruction. Through the regulation of trafficking, proliferation, and maturation of inflammatory cells, cytokines are likely to have a vital role in the immune dysregulation that results in disease morbidity. ${ }^{1}$ Despite their importance, cytokine profiles in the SpA, whether in serum or within inflammatory cells, are largely unknown. Elucidating the role of cytokines in these disorders has important diagnostic and therapeutic significance: in rheumatoid arthritis (RA), for example, high levels of tumour necrosis factor (TNF) have been found in synovial tissue; inhibition of this proinflammatory cytokine has been shown in clinical trials to significantly reduce acute disease severity. ${ }^{2-4}$

The differentiation of cytokines into proinflammatory and anti-inflammatory types may help to simplify the evaluation of serum cytokine levels in the SpA. In addition to $\mathrm{TNF} \alpha$, other cytokines typically considered to be proinflammatory include interferon gamma (IFN $\gamma$ ), interleukin (IL) 1, and IL6; these molecules have been associated with $\mathrm{T}$ and $\mathrm{B}$ cell differentiation, lymphocyte and monocyte chemotaxis, and the induction of acute phase reactants, respectively. In contrast, anti-inflammatory cytokines, including IL4 and IL10, block monocyte production of ILl, TNF $\alpha$, and IL6. ${ }^{1}$ Although multiple leucocyte types produce these cytokines, it has been suggested that the selective production of these cytokines by different subtypes of CD4+ T cells has an important role in the pathogenesis of many rheumatic diseases. ${ }^{5}$ Thl-type $\mathrm{T}$ cells, secreting IFN $\gamma$ and IL2, promote cell mediated immunity; Th2 T cells, producing IL4 and IL10, favour the formation of humoral immunity. It is the imbalance of Th1/Th2 cytokine production, as quantified by flow cytometry, which has been the focus of multiple studies on cytokine evaluation in the SpA. Examination of both serum and intracellular cytokine levels has the potential to elucidate valuable information about acute disease severity and response to treatment in the seronegative SpA.

\section{SERUM CYTOKINE LEVELS AND CYTOKINE PROFILES WITH TNF BLOCKER TREATMENT IN THE SPA}

In general, there is disagreement about the serum levels of proinflammatory cytokines in the SpA, particularly TNF $\alpha$, IL6, and ILl $\beta$. Several studies have shown that TNF $\alpha$ levels are raised at baseline in patients with SpA. Gratacos et al were one of the first groups to evaluate serum cytokine levels in ankylosing spondylitis (AS). ${ }^{6}$ Serum from 69 patients with AS and 36 controls with non-inflammatory back pain was analysed for cytokine profiles by an enzyme linked immunosorbent assay (ELISA). TNF $\alpha$ levels were raised in patients with AS (mean (SD) $14 \quad$ (11) pg/ml) compared with patients with non-inflammatory back pain (7.5 (13), $p=0.016)$. IL6 levels were also higher in patients with AS (19.8 (4.7) pg/ml $v 2.3(2.8)$, $\mathrm{p}<0.0001)$. No significant difference in IFN $\gamma$ levels was found, and ILl $\beta$ was not detectable in either group.

Sonel et al obtained similar results to those of Gratacos et al. ${ }^{7}$ In 42 patients with SpA, serum was analysed for TNF $\alpha$ and ILI $\beta$ by ELISA. Cytokine levels were compared between healthy controls, patients with SpA with active disease,

Abbreviations: AS, ankylosing spondylitis; BASFI, Bath Ankylosing Spondylitis Functional Index; ELISA, enzyme linked immunosorbent assay; ESR, erythrocyte sedimentation rate; IFN $\gamma$, interferon gamma; IL, interleukin; LPLs, lamina propria lymphocytes; MEI, Modified Enthesopathy Index; OA, osteoarthritis; PBMCs, peripheral blood mononuclear cells; PMA, phorbol myristate acetate; $\mathrm{Ps}$, psoriatic arthritis; $\mathrm{RA}$, rheumatoid arthritis; RT-PCR, reverse transcriptase-polymerase chain reaction; SpA, spondyloarthropathies; TGF, transforming growth factor; TNF, tumour necrosis factor 
and those with inactive disease. Both SpA groups with active (13.24 (7.45) pg/ml) and inactive disease (11.42 (6.70)) had higher serum TNF $\alpha$ levels than controls (8.27 (5.20), $\mathrm{p}<0.05)$. There was no significant difference between controls and patients with SpA for ILl $\beta$; neither TNF $\alpha$ nor ILl $\beta$ differed significantly between patients with SpA with active or inactive disease.

Toussirot et al reported no significant difference in ILl $\beta$ levels, and only a trend towards increased TNF $\alpha$ levels in patients with SpA compared with healthy controls. ${ }^{8}$ Thus, while all three trials found no increased serum levels of ILl $\beta$ in patients with $\mathrm{SpA}$, there appear to be preliminary data suggesting that serum TNF $\alpha$ levels are raised in the SpA.

In addition to examining the levels of serum cytokines, others have evaluated the correlation of cytokine levels with disease activity. Claudepierre et al analysed serum from patients with SpA for IL1 $\beta$, IL6, TNF $\alpha$, IL10, and transforming growth factor $\beta 1$ (TGF $\beta 1$ ) levels using ELISA or radioimmunoassay.9 ${ }^{10}$ IL6 levels correlated with erythrocyte sedimentation rate (ESR: $r=0.71, \mathrm{p}<0.01$ ); there was also a fivefold increase of IL6 in patients with peripheral arthritis compared with those without $(40.5 \vee 15.6 \mathrm{pg} / \mathrm{ml}, \mathrm{p}<0.05)$. TGF $\beta 1$, a cytokine associated with the induction of tissue fibrosis, was twofold higher in patients with reported back pain than in those without $(25.7 \vee 7.2 \mathrm{ng} / \mathrm{ml}, \mathrm{p}<0.05) .{ }^{1}{ }^{9}$ Finally, seven patients with SpA with serum IL10 levels $>7.8 \mathrm{pg} / \mathrm{ml}$ had significantly longer periods of morning stiffness (median 1.5 hours in the high IL10 group $v$ 0.7 hours, $\mathrm{p}<0.01)$ and higher pain visual analogue scale scores $(6.1 \mathrm{~cm} v 3.5 \mathrm{~cm}, \mathrm{p}<0.01)$ than patients with SpA with lower levels of IL10. These studies are limited by the lack of a healthy control comparator, but the data do provide some evidence for an increase of both inflammatory (IL6) and antiinflammatory (IL10) cytokines in active SpA.

\section{"Serum levels of both inflammatory (IL6) and anti- inflammatory (IL10) cytokines seem to be increased in active $\mathrm{Sp} \mathrm{A}^{\prime \prime}$}

Synovial fluid and tissue samples from patients with SpA have also been analysed. Ritchlin et al evaluated protein cytokine levels in synovial tissue biopsy specimens from patients with psoriatic arthritis (PsA) $(n=8), R A(n=7)$, and osteoarthritis (OA) $(\mathrm{n}=9) .{ }^{11}$ Synovial membrane was isolated and cultured in medium for 10 days and ELISA was used to determine cytokine levels. The PsA samples produced significantly more ILl $\beta(\mathrm{p}<0.03 v \mathrm{RA}, \mathrm{p}<0.001 v$ OA), IL2 $(\mathrm{p}<0.05 v \mathrm{RA}, \mathrm{p}<0.04 v$ OA), IL10 $(\mathrm{p}<0.02 v \mathrm{RA}, \mathrm{p}<0.0004 v$ $\mathrm{OA})$, and IFN $\gamma(\mathrm{p}<0.02 v \mathrm{RA}, \mathrm{p}<0.004 v \mathrm{OA})$ than either the RA or OA groups. Production of TNF $\alpha$ was similar in all three groups, and none of the samples produced IL4 or IL5. Canete et al measured synovial fluid cytokine levels in both patients with SpA and those with RA. ${ }^{12}$ RA synovial fluid had higher levels of ILl $\beta$ than samples from patients with SpA (22 (18) $\mathrm{pg} / \mathrm{ml} v 12$ (23), $\mathrm{p}<0.05)$; there was no difference in protein IL6 or TNF $\alpha$ levels.

Brandt et al performed one of the few studies on serum cytokine modification in active AS after TNF blockade. ${ }^{13}$ Eleven patients with AS of short duration $(<5$ years) but with active disease had serum levels of IL6 measured at baseline and after three doses of infliximab over six weeks. At baseline, the median IL6 level was $12.4 \mathrm{ng} / \mathrm{l}$ (range 0-28.9), with 6/11 patients having raised levels (normal $<5 \mathrm{ng} / \mathrm{l}$ ). After treatment, the 10 participants remaining in the study all had serum IL6 levels $<5 \mathrm{ng} / \mathrm{l}$.

Our group evaluated the role of anti-TNF treatment on cytokine profiles in AS. Serum cytokine levels of TNF, ILl $\beta$, and IL6 were measured in 25 patients with moderate to severe AS before and after treatment with either etanercept $25 \mathrm{mg}$ or placebo subcutaneously twice a week for four months. ${ }^{14}$ In addition, serum samples from 10 healthy controls were also analysed. Samples were frozen at $-70^{\circ} \mathrm{C}$, batched, and measured by radioimmunoassay or ELISA (Quest Diagnostics' Nichols Institute, San Juan Capistrano, CA). Other markers of disease activity were measured before and after treatment, including: ESR, morning back stiffness, Bath Ankylosing Spondylitis Functional Index, and Modified Enthesopathy Index..$^{16}$ Table 1 shows the results obtained: the findings suggest that baseline levels of Thl cytokines are not raised in the serum of patients with moderate, active AS. They are not higher than normal reference values in healthy control subjects. These baseline levels did not correlate with multiple disease activity measures for AS. Furthermore, treatment with anti-TNF did not change cytokine profiles, although multiple other measures of disease activity were reduced.

\begin{tabular}{|c|c|c|c|c|}
\hline & $\begin{array}{l}\text { Controls } \\
(n=10)\end{array}$ & $\begin{array}{l}\text { All AS } \\
\text { baseline } \\
(n=25)\end{array}$ & $\begin{array}{l}\text { Etanercept } \\
(n=13)\end{array}$ & $\begin{array}{l}\text { Placebo } \\
(n=12)\end{array}$ \\
\hline Mean age (years) & 30 & 40 & 42 & 39 \\
\hline$\%$ Male & 40 & 80 & 70 & 92 \\
\hline \% HLA-B27+ & - & 92 & 92 & 92 \\
\hline$\%$ White & 60 & 72 & 85 & 58 \\
\hline Mean ESR $(\mathrm{mm} / 1 \mathrm{st} h)$ & - & 31 & $\begin{array}{l}38 \text { before } \\
13 \text { after }\end{array}$ & $\begin{array}{l}27 \text { before } \\
22 \text { after }\end{array}$ \\
\hline Morning stiffness (min) & - & 84 & $\begin{array}{l}98 \text { before } \\
21 \text { after }\end{array}$ & $\begin{array}{l}69 \text { before } \\
55 \text { after }\end{array}$ \\
\hline BASFI (0-10) & - & 4.8 & $\begin{array}{l}5.4 \text { before } \\
3.0 \text { after }\end{array}$ & $\begin{array}{l}4.3 \text { before } \\
3.9 \text { after }\end{array}$ \\
\hline MEI (0-51) & - & 7 & $\begin{array}{l}7.7 \text { before } \\
1.8 \text { after }\end{array}$ & $\begin{array}{l}6.5 \text { before } \\
2.8 \text { after }\end{array}$ \\
\hline TNF $\alpha$ (reference $<50 \mathrm{pg} / \mathrm{ml}$ ) & $<12.8$ & $<12.8$ & $\begin{array}{l}<12.8 \\
\text { before/after }\end{array}$ & $\begin{array}{l}<12.8 \\
\text { before/after }\end{array}$ \\
\hline Interleukin $\beta$ (reference $<150$ pg/ml) & 120 & 73 & $\begin{array}{l}82 \text { before } \\
73 \text { after }\end{array}$ & $\begin{array}{l}63 \text { before } \\
77 \text { after }\end{array}$ \\
\hline Interleukin 6 (reference $<62 \mathrm{pg} / \mathrm{ml}$ ) & 33.2 & 13.0 & $\begin{array}{l}16 \text { before } \\
10 \text { after }\end{array}$ & $\begin{array}{l}10 \text { before } \\
10 \text { after }\end{array}$ \\
\hline
\end{tabular}


In summary, the data featuring serum and synovial fluid cytokines have produced varying results. Two trials have shown raised TNF $\alpha$ levels in SpA serum. ${ }^{67} \mathrm{~A}$ number of inflammatory cytokines in synovial tissue from patients with PsA were raised, although the in vitro growth of synovium in the study may not be representative of cytokine production in active disease. ${ }^{11}$ High levels of serum IL6 in patients with AS at baseline dropped significantly after treatment with infliximab. ${ }^{13}$ These results correlate with the concept that SpA is an inflammatory process, with high serum levels of proinflammatory cytokines mediating tissue destruction. However, our data found neither a significant increase in baseline serum inflammatory cytokines in patients with AS compared with healthy controls nor a change after anti-TNF treatment. A non-significant increase of $\mathrm{TNF} \alpha$ serum values in patients with SpA compared with controls was found in another trial, while a third study described lower levels of the Thl cytokine ILl $\beta$ in synovial fluid from patients with SpA compared with those with RA. ${ }^{8}{ }^{12}$ IL10, a cytokine known for its anti-inflammatory effects, was shown to correlate with certain symptoms of active SpA. ${ }^{10}$ Therefore, it appears that the production of global cytokine levels in SpA is more complex than a simple proliferation of proinflammatory cytokines. One hypothesis involves a multifaceted interplay of various cytokine types, with local areas of proinflammatory cytokine production regulated at times by a global release of inhibitory cytokines. ${ }^{17}{ }^{18}$ The balance and feedback control of these proteins makes the interpretation of levels difficult, although a role for certain cytokines as markers of active disease may be disclosed through future research.

\section{INTRACELLULAR CYTOKINE PROTEIN EXPRESSION IN PERIPHERAL BLOOD T CELLS}

A significant factor in the analysis of cytokine profiles is the difficulty in accurately measuring serum cytokine levels. One challenge lies in the fluctuation of serum levels because cytokines have short half lives and vary widely at different locations throughout the body. ${ }^{19}$ The complexity of cytokines in synovial inflammation or enthesopathy, for example, may not be reflected accurately in serum levels.

\section{"Measurement of cytokines is difficult because they have short half lives and levels vary throughout the body"}

In addition, serum cytokines may be produced by any number of leucocyte types, including monocytes, neutrophils, and lymphocytes. ${ }^{1}$ To make any statements about the specific role of $\mathrm{T}$ cells in cytokine production (including the Thl/Th2 balance of cytokines), flow cytometry must be used to identify the presence of CD markers. For these reasons, many researchers have begun to measure intracellular cytokine protein expression in $\mathrm{CD} 3+$ peripheral blood mononuclear cells (PBMCs). Most of these studies performed on serum isolated PBMCs from blood samples, stimulated the cells with phorbol myristate acetate (PMA)/ionomycin, then measured cytokine and $\mathrm{T}$ cell marker expression by flow cytometry.

Rudwaleit et al evaluated cytokine expression in PBMCs from patients with AS using flow cytometry. ${ }^{20}$ Twenty five HLA-B27+ patients with AS, as well as 18 healthy HLA-B27+ controls and 22 healthy HLA-B27- controls were studied. They reported significant reductions in the percentages of CD4+ and CD8+ cells expressing intracellular TNF $\alpha$ both in patients with AS and HLA-B27+ controls compared with HLA-B27- controls (CD4: median $5.11 \%, \mathrm{p}<0.008$ for AS; $7.48 \%, \mathrm{p}<0.034$ for HLA+; $9.5 \%$ for HLA-B27-; CD8: $2.65 \%$, $\mathrm{p}=0.0003$ for AS; $4.08 \%, \mathrm{p}=0.012$ for HLA-B27+, $7.32 \%$ for HLA-B27-). There were also reductions in IFN $\gamma$ expression in both CD4+ and CD8+ cells of patients with AS and HLAB27+ controls compared with HLA-B27- controls (CD4: median $8.73 \%, p=0.003$ for AS; $10.57 \%, p=0.005$ for HLAB27+; $14.76 \%$ for HLA-B27-; CD8: $24.87 \%, p=0.002$ for AS; $25.55 \%, p=0.018$ for HLA-B27+; $36.44 \%$ for HLA-B27-). IL10 production of CD8+ cells was higher in patients with AS $(0.81 \%)$ than in HLA-B27+ controls $(0.29 \%, p<0.001)$ and HLA-B27 - controls $(0.39 \%, p=0.012)$; otherwise, the difference in IL4 and IL10 levels between groups was not significant. These data suggest a reduction in Thl cytokines (IFN $\gamma, \mathrm{TNF} \alpha$ ) in HLA-B27+ patients, including healthy controls, in addition to those with active SpA.

In a study that examined gut lymphocytes from colonic and ileal biopsy samples in 20 patients with SpA and compared their expression of cytokines with gut lymphocytes isolated from 13 healthy controls, Van Damme et al reported similar findings to Rudwaleit et al. ${ }^{21}$ A significant decrease of IFN $\gamma$-producing SpA colonic CD3+ lamina propria lymphocytes (LPLs: median 64\% control cells $v 54 \%$ SpA, $\mathrm{p}=0.02$ ), as well as decreased expression of IFN $\gamma$ and IL2 in CD3+ CD8 - LPLs of the colon (IFN $\gamma: 57 \% v 47 \%, \mathrm{p}=0.021$ and IL2: $74 \%$ v $67 \% \mathrm{p}=0.027$ ) was found. IL10 levels were increased among SpA CD3+ CD8 - LPLs in the ileum (2.4\% control cells $v 3.4 \% \mathrm{SpA}, \mathrm{p}=0.046)$. Although only a small fraction of the SpA lymphocytes examined showed any significant change over control cells, the results also suggest a reduced Thl gut cytokine profile in patients with SpA.

Zou et al analysed cytokines from two placebo controlled trials in AS: one with infliximab, the other with etanercept. $^{22}{ }^{23}$ In the infliximab trial, PBMCs were isolated at baseline and after 12 weeks of treatment in 10 patients with AS; an additional 10 patients with AS received doses of placebo for six weeks. After stimulation with PMA/ionomycin, the group found a significant decrease in the percentages of both CD4+ and CD8+ cells producing IFN $\gamma$ and TNF $\alpha$ after 12 weeks of infliximab treatment (CD4: IFN $\gamma$ median $16.5 \%$ before treatment $v 8.1 \%$ after treatment, $\mathrm{p}=0.005$; $\mathrm{TNF} \alpha$ $18.4 \%$ 5.6\%, $\mathrm{p}=0.005$; CD8: IFN $\gamma 35.7 \%$ v 20.4\%, $\mathrm{p}=0.005$; $\mathrm{TNF} \alpha 23.8 \% \vee 4.3 \%, \mathrm{p}=0.005)$. There were no significant changes in IL4 or IL10 production after treatment compared with baseline. In contrast, the etanercept trial demonstrated a significant increase in IFN $\gamma$ and TNF $\alpha$ expression in CD4+ cells 12 weeks after treatment $(\mathrm{p}<0.05)$. One explanation is that the interaction of infliximab with the TNF $\alpha$ receptor down regulates Thl cytokines; in contrast, etanercept binds TNF molecules and may up regulate Thl protein production secondary to low circulating TNF levels. ${ }^{23}$

Unfortunately, there are conflicting results of cytokine modification with infliximab treatment. Braun et al reported cytokine measurements in six patients with AS before and after infliximab treatment. ${ }^{19}$ The group, essentially the same as in the Zou et al paper and using a similar protocol, isolated PBMCs from patients at baseline and after two weeks of antiTNF treatment: $\mathrm{TNF} \alpha+\mathrm{CD} 3+$ cells were found to increase from $5.6 \%$ at baseline to $9.9 \%$ at week 2 . According to the group, they also "found a stronger IFN $\gamma$ secretion after infliximab treatment compared with pretreatment values," but the data were not expressly given. Baeten et al also evaluated 20 patients with SpA with active disease treated with three doses of infliximab compared with 15 healthy controls. ${ }^{24}$ PBMCs were isolated from blood at baseline and throughout the study (until day 83, 42 days after the final infliximab infusion). Similar to Rudwaleit et al, a greater proportion of $\mathrm{CD} 3+$ cells in healthy controls at baseline were significantly positive compared with SpA CD3+ cells for IFN $\gamma$ (median 33.0\% $v 20.9 \%, \mathrm{p}<0.05)$ and IL2 $(25.7 \% \vee 17.5 \%$, $\mathrm{p}<0.05$ ). Conversely, a larger proportion of SpA CD3+ cells were positive compared with those of healthy controls for IL10 (3.8\% SpA $v 1.1 \%, \mathrm{p}<0.05)$; there was no significant 
difference between samples for IL4 at baseline. After infliximab treatment, there was a rise in IFN $\gamma(20.9 \%$ baseline to $32.7 \%$ day $84, \mathrm{p}<0.002$ ) and IL2 levels $(17.5 \%$ to $32.6 \%, \mathrm{p}<0.001$ ) in SpA PBMCs compared with baseline. There was no change in IL4 and ILl0 levels after the treatment period.

These data seem to suggest that before treatment with anti-TNF, Thl cytokine levels are lower in patients with SpA than in healthy controls. The data after TNF inhibition, however, are less clear. In similarly performed trials with infliximab in patients with SpA, PBMCs stimulated with PMA/ionomycin produced either higher or lower levels of Thl cytokines. ${ }^{19} 2224$ Although the results appear contradictory, it may underline the complexity of cytokine regulation: variations in local tissue cytokine expression in patients with different degrees of active disease may cause wide fluctuations of cytokine production in peripheral blood. Additionally, the discrepancy in the data may demonstrate the artificial nature of stimulating cytokine production before measurement. Clearly, further studies, including those using methods other than synthetic stimulation of mononuclear cells to express cytokines, are warranted.

\section{CYTOKINE mRNA EXPRESSION IN MONONUCLEAR CELLS}

Investigators have also examined cytokine gene expression in the SpA. Although it is not possible to isolate T cells by this technique, important data can be inferred about the intracellular concentrations of cytokine mRNA without having to stimulate the cells artificially. Only one study, performed by Gu et al, has analysed cytokine gene expression in peripheral blood; the trial evaluated PBMCs in patients with SpA and RA with active disease. ${ }^{25}$ Total RNA was extracted and purified, then screened for cytokine RNA by a microarray assay technique. Cytokine RNA levels deemed positive by the microarray were amplified in a semiquantitative manner using reverse transcriptase-polymerase chain reaction (RT-PCR). ILl $\beta$ gene expression was at least fivefold higher in SpA (24 (56), given in relative PCR units) and RA $(40(74))$ than in healthy controls $(1.1(0.6))$. However, there was no significant difference in $\mathrm{TNF} \alpha$ or IFN $\gamma$ levels compared with controls. This paper did not demonstrate the reduced proinflammatory cytokine profile seen in the PBMC flow cytometry studies. ${ }^{20} 2124$ In three trials measuring intracellular protein levels with flow cytometry, T cells were identified and stimulated with PMA/ionomycin; in the Gu et al study, the PBMCs were undifferentiated and not stimulated. The difference in these results may be due to differences in $\mathrm{T}$ cell and monocyte/macrophage cytokine production, PBMC activity with and without stimulation, or the inherent difficulties in comparing levels of RNA expression with actual protein translation. In any case, they provide further evidence that cytokine production in the SpA may involve a complex interplay between pro- and antiinflammatory cytokine profiles based on disease activity, inflammatory cell type, and location of inflammation.

A limited number of mRNA trials with synovial tissue have produced inconsistent results, with variable degrees of proand anti-inflammatory cytokine genes expressed. Braun et al examined cytokine levels in sacroiliac joint biopsy specimens of five patients with active AS. ${ }^{26}$ Using radioisotope labelled antisense RNA probes and photoemulsion to visualise in situ hybridisation, the group described the presence of "abundant message of TNF $\alpha$, but no message for ILl $\beta$ " under microscopy. Canete et al analysed cytokine profiles of synovial tissue in both RA and patients with $\mathrm{SpA} .{ }^{27} \mathrm{RNA}$ was extracted and amplified with RT-PCR in all patients. The data were presented as a percentage of the number of patients in each group who had detectable DNA. The group reported comparable expression of IL1 $\beta$ (94\% RA $v 69 \%$ SpA), IL2 (12.5\% $v$ $6.25 \%)$, IL6 (50\% $v 44 \%), \operatorname{TNF} \alpha(37.5 \% \vee 31.2 \%)$, and TGF $\beta$ $(81 \% v 68.8 \%)$ in both groups. IL4 and IL5 were undetectable in all patients. There were no significant differences in cytokine expression between patients with disease of long duration (>12 months) and short duration $(<12$ months) in either group.

A second study by Canete et al compared the profiles of cytokine mRNA expression in the synovial tissue of 14 patients with SpA with those of 11 patients with RA. ${ }^{12}$ All patients had active knee synovitis, and active inflammation in the synovial tissue sampled was confirmed by haematoxylin/eosin staining. Using the ratio of each cytokine mRNA to CD3 mRNA to balance variations in lymphocyte counts, only the IFN $\gamma / \mathrm{CD} 3$ ratio was significantly higher in RA samples (mean (SD) 0.56 (0.66) RA $v 0.14$ (0.28) SpA, p<0.003). There was no difference in the mRNA cytokine/CD3 ratios of IL2, IL4, IL5, or IL10 between the two groups. The IFN $\gamma /$ IL4 mRNA ratio was five times higher in the RA samples (5.5 RA $v$ 1.1 SpA). A second study by $\mathrm{Gu}$ et al compared cytokine profiles in the synovial fluid mononuclear cells of five patients with SpA, with PBMCs in six healthy controls. ${ }^{28}$ Gene expression was again screened using a microarray; cytokine RNA was then amplified using RT-PCR. IL8 (0.9 control $v 314.0 \mathrm{SpA}, \mathrm{p}=0.001), \operatorname{ILl} \beta(1.2 v 5.2, \mathrm{p}=0.002)$, $\operatorname{IFN} \gamma(0.7 v 1.3, \mathrm{p}=0.016), \operatorname{TGF} \beta(2.9 \vee 33, \mathrm{p}=0.001)$, and IL2R $\alpha(1.0 \vee 70, \mathrm{p}=0.003)$ were all significantly greater in SpA mononuclear cells; there was no significant difference in TNF $\alpha$ or IL6 production between SpA mononuclear cells and controls.

It is difficult to draw firm conclusions based on the limited number of studies available analysing cytokine mRNA production of cells from synovium in SpA. The results of several trials suggest that proinflammatory synovial cytokine production is raised in RA and SpA, with undetectable levels of the anti-inflammatory cytokines IL4 and IL5 in the Canete et al study and high levels of the proinflammatory cytokines IFN $\gamma$ and IL1 $\beta$ compared with controls in the Gu et al trial. ${ }^{28}$ However, the lower degree of IFN $\gamma$ in synovial SpA compared with RA, along with the markedly decreased ratio of IFN $\gamma /$ IL4 in patients with SpA compared with those with RA in the second Canete et al study imply a greater role for antiinflammatory cytokine gene expression in SpA than in RA, even in local areas of macroscopic synovial inflammation. ${ }^{12}$

\section{CONCLUSION}

A number of studies have examined cytokine levels in the SpA with the aim of: $(a)$ delineating the types of cytokines expressed; $(b)$ identifying inflammatory cell types with prominent cytokine levels; and (c) demonstrating the influence of TNF blocker treatment on cytokine profiles. From these trials, several points can be made. Firstly, serum cytokine studies have produced varying results. Although there is a general trend toward raised serum proinflammatory cytokines (particularly TNF $\alpha$ ) in the SpA, several trials found either no increase in serum proinflammatory cytokine levels or a significant increase in serum anti-inflammatory cytokines. Our work also found no significant increase in baseline serum proinflammatory cytokines in patients with AS compared with controls. In addition, these cytokine levels did not change after anti-TNF treatment. In our study, neither controls nor the patients treated had detectable levels of TNF $\alpha$; therefore, we cannot rule out subtle changes in $\mathrm{TNF} \alpha$ associated with inflammation that were not detected by our assays. This underlines the concept that exact measurement of serum cytokines is difficult, owing to short cytokine half lives, variations in ELISA measurements, and complex cytokine fluctuations varying with the state of inflammation in individual patients. The wide variation in 
serum cytokine measurements lessens their current applicability as markers for disease activity or therapeutic response.

Secondly, analysis of peripheral T cells for cytokine protein expression has produced fairly uniform data, demonstrating a shift toward a reduced Thl cytokine profile in patients with SpA compared with controls. In three trials, intracellular levels of several Thl cytokines were increased in SpA disorders. ${ }^{202124}$ Although it is tempting to state that the balance is shifted in favour of a Th2 profile in the SpA, these trials found raised levels of IL10 in a limited number of cell lines, and did not find significantly higher levels of IL4. The reduction of peripheral blood $\mathrm{T}$ cell Thl cytokine levels may indicate a systemic dysregulation of the cell mediated immune response in the $\mathrm{SpA}$, or they may simply be a counterregulatory response to the high levels of Thl cytokines in areas of active inflammation.

The effects of anti-TNF treatment on intracellular SpA cytokine profiles may depend on the mechanism of blockade. Some preliminary data suggest that infliximab down regulates Thl cytokines, while etanercept binds TNF molecules and up regulates serum Thl protein expression. The conflicting data with infliximab treatment may indicate that even when taking intracellular cytokine measurements, there are substantial variations based on the degree of inflammation within individual patients or throughout the time course of the disease.

Studies measuring cytokine RNA production from mononuclear cells have also produced inconsistent results, particularly for samples taken from inflamed synovium. Like serum cytokine levels, the variation in RNA data may arise from the fact that the nucleic acid measurements represent cytokine production from all mononuclear cells, not just $\mathrm{T}$ cells. Variations seen in $\mathrm{T}$ cell cytokine profiles, for example, may not be accurately reflected in circulating monocytes. Overall, there is no clear delineation of the cytokine balance seen in PBMCs based on the current RNA research.

The most valuable data in the future will continue to come from studies of intracellular cytokine protein levels, in which $\mathrm{T}$ cells can be selectively analysed for Thl/Th2 cytokine specificity. The major concern with intracellular protein measurements lies in the use of artificial stimulation; at this time, however, it remains our most specific tool for obtaining a better understanding of the role of cytokines in the pathogenesis and prognosis of the SpA. An important next step in drug trials with TNF and other inflammatory cytokine inhibitors would be to continue to differentiate different disorders within the seronegative SpA. Although it is often necessary to group these rare disorders together to increase the power of studies, cytokine levels in PsA, for example, may not be representative of those in reactive arthritis. As trials begin to focus more on particular disease states and on specific inflammatory cell types, the data obtained will be of greater use in defining specific treatments and clarifying the pathogenesis of these disorders.

\section{ACKNOWLEDGEMENTS}

This work was supported by NIAMS/NIH N01-AR-9-2244, Immunex Corporation, Seattle Washington, and The Rosalind Russell Medical Research Center for Arthritis Research University of California San Francisco, USA

\section{Authors' affiliations}

C Keller, A Webb, J Davis, University of California San Francisco, San Francisco, California, USA

\section{REFERENCES}

1 Dayer JM, Arend WP. Cytokines and growth factors. In: Kelley WN, et al, eds. Textbook of Rheumatology, 5th ed. Philadelphia: Saunders, 1997.
2 Chu CQ, Field M, Feldmann M, Maini RN. Localization of tumor necrosis factor $\alpha$ in synovial tissues and at the cartilage-pannus junction in patients with rheumatoid arthritis. Arthritis Rheum 1991;34:1125-32.

3 Lipsky PE, van der Heijde DM, St Clair EW, Furst DE, Breedveld FC, Kalden JR, et al. Infliximab and methotrexate in the treatment of rheumatoid arthritis. Anti-Tumor Necrosis Factor Trial in Rheumatoid Arthritis with Concomitant Therapy Study Group. N Engl J Med 2000;343:1594-602.

4 Moreland LW, Schiff MH, Baumgartner SW, Tindall EA, Fleischmann KJ, et al. Etanercept therapy in rheumatoid arthritis. A randomized controlled trial. Ann Intern Med 1999; 130:478-86.

5 Miossec $\mathbf{P}$, van den Berg W. Th1/Th2 cytokine balance in arthritis. Arthritis Rheum 1997:40:2105-15.

6 Gratacos J, Collado A, Filella X, Sanmarti R, Canete J, Llena J, et al. Serum cytokines (IL-6, TNF- $\alpha$, IL-1 $\beta$ and IFN- $\gamma$ ) in ankylosing spondylitis: a close correlation between serum IL- 6 and disease activity and severity. Br J Rheumatol 1994:33:927-31.

7 Sonel B, Tutkak H, Duzgun N. Serum levels of IL-1 beta, TNF-alpha, IL-8, and acute phase proteins in seronegative spondyloarthropathies. Joint Bone Spine 2002;69:463-7.

8 Toussirot $E$, Lafforgue $P$, Boucraut J, Despieds $P$, Schiano A, Bernard D, et al. Serum levels of interleukin 1- $\beta$, tumor necrosis factor- $\alpha$, soluble interleukin 2 receptor and soluble CD8 in seronegative spondyloarthropathies. Rheumatol Int 1994; 13:175-80.

9 Claudepierre P, Rymer J-C, Authier F-J, Allanore Y, Larget-Piet B, Gherardi R, et al. A relationship between TGF- $\beta 1$ or IL- 6 plasma levels and clinical features of spondyloarthropathies. Br J Rheumatol 1997;36:400-6.

10 Claudepierre P, Rymer J-C, Chevalier X. IL-10 plasma levels correlate with disease activity in spondyloarthropathy. J Rheumatol 1997;24:1659-61.

11 Ritchlin C, Haas-Smith SA, Hicks D, Cappuccio J, Osterland CK, Looney RJ. Patterns of cytokine production in psoriatic synovium. J Rheumatol 1998;25: 1544-52.

12 Canete JD, Martinez SE, Farres J, Sanmarti R, Blay M, Gomez A, et al. Differential Th1/Th2 cytokine patterns in chronic arthritis: interferon $\gamma$ is highly expressed in synovium of rheumatoid arthritis compared with seronegative spondyloarthropathies. Ann Rheum Dis 2000;59:263-8.

13 Brandt J, Haibel H, Cornely D, Golder W, Gonzalez J, Reddig J, et al. Successful treatment of active ankylosing spondylitis with the anti-tumor necrosis factor $\alpha$ monoclonal antibody infliximab. Arthritis Rheum 2000;43:1346-52

14 Gorman JD, Sack KE, Davis JC Jr. Treatment of ankylosing spondylitis by inhibition of tumor necrosis factor alpha. N Engl J Med 2002;346:1349-56.

15 Calin A, Garrett S, Whitelock H, O'Hea J, Mallorie P, Jenkinson T. A new approach to defining functional ability in ankylosing spondylitis: the development of the Bath Ankylosing Spondylitis Functional Index. J Rheumatol 1994:21:2281-5.

16 Mander M, Simpson JM, Mclellan A, Walker D, Goodacre JA, Dick WC. Studies with an enthesis index as a method of clinical assessment in ankylosing spondylitis. Ann Rheum Dis 1987;46:197-202.

17 Braun J, de Keyser F, Brandt J, Mielants H, Sieper J, Veys E. New treatment options in spondyloarthropathies: increasing evidence for significant efficacy of anti-tumor necrosis factor therapy. Curr Opin Rheumatol 2001;13:245-9.

18 Braun J, Sieper J, Breban M, Collantes-Estevez E, Davis J, Inman R, et al. Antitumour necrosis factor $\alpha$ therapy for ankylosing spondylitis: international experience. Ann Rheum Dis 2002;61(suppl III):iii51-60.

19 Braun J, Xiang J, Brandt J, Maetzel H, Haibel H, Wu P, et al. Treatment of spondyloarthropathies with antibodies against tumor necrosis factor $\alpha$ : first clinical and laboratory experiences. Ann Rheum Dis 2000;59(suppl I):185-9.

20 Rudwaleit M, Siegert S, Yin Z, Eick J, Thiel A, Radbruch A, et al. Low T cell production of TNF $\alpha$ and IFN $\gamma$ in ankylosing spondylitis: its relation to HLA-B27 and influence of the TNF-308 gene polymorphism. Ann Rheum Dis $2001 ; 60: 36-42$

21 Van Damme N, De Vos M, Baeten D, Demetter P, Mielants H, Verbruggen G, et al. Flow cytometric analysis of gut mucosal lymphocytes supports an impaired Thl cytokine profile in spondyloarthropathy. Ann Rheum Dis 2001:60:495-9.

22 Zou JX, Rudwaleit M, Brandt J, Thiel A, Braun J, Sieper J. Down-regulation of the nonspecific and antigen-specific T cell cytokine response in ankylosing spondylitis during treatment with infliximab. Arthritis Rheum 2003:48:780-90.

23 Zou JX, Braun J, Sieper J. Immunological basis for the use of TNF $\alpha$-blocking agents in ankylosing spondylitis and immunological changes during treatment. Clin Exp Rheumatol 2002;20(suppl 28):34-7.

24 Baeten D, Van Damme N, Van den Bosch F, Kruithof E, De Vos M, Mielants H, et al. Impaired Th1 cytokine production in spondyloarthropathy is restored by anti-TNF $\alpha$. Ann Rheum Dis 2001;60:750-5.

25 Gu J, Marker-Hermann E, Baeten D, Tsai WC, Gladman D, Xiong M, et al. A 588 -gene microarray analysis of the peripheral blood mononuclear cells of spondyloarthropathy patients. Rheumatology (Oxford) 2002:41:759-66.

26 Braun J, Bollow M, Neure L, Seipelt E, Seyrekbasan F, Herbst H, et al. Use of immunohistologic and in situ hybridization techniques in the examination of sacroiliac joint biopsy specimens from patients with ankylosing spondylitis. Arthritis Rheum 1995;38:499-505.

27 Canete JD, Llena J, Collado A, Sanmarti R, Gaya A, Gratacos J, et al. Comparative cytokine gene expression in synovial tissue of early rheumatoid arthritis and seronegative spondyloarthropathies. $\mathrm{Br} J$ Rheumatol 1997:36:38-42.

28 Gu J, Rihl M, Marker-Hermann E, Baeten D, Kuipers JG, Song YW, et al. Clues to pathogenesis of spondyloarthropathy derived from synovial fluid mononuclear cell gene expression profiles. J Rheumatol 2002;29:2159-64. 